\title{
Original
}

\section{Effect to Apatite-containing Dentifrices on

\author{
Dental Caries in School Children
}

\author{
アパタイト配合歯磨剤の児童における \\ う蝕に及ぼす影響について
Tokuko KANI*, Mizuo KANI*, Atsunori ISOZAKI*, Hirohisa SHINTANI* , Tamie OHASHI ${ }^{*}$ and Tatsuhiro TOKUMOTO* \\ 可 児徳子* 可児瑞夫* 磯崎 篤 則 * \\ 新谷 裕 久* 大橋たみえ* 徳本龍 弘*
}

\section{Received October 22, 1988 ; accepted November 29, 1988}

\begin{abstract}
舫要：学校齿科保健の場において，小学校児童を対象に，合成ハイドロキシアパタイト5\%配合歯磨刜を 用いて学校給食後にブラッシングを実施した。対照群児童には合成ハイドロキシアパタイトのみを除外した

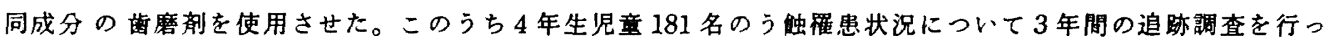
た。その結果, 総萌出歯の一人平均 DMFT 数は男子, 女子ともにアパタイト配合歯磨郕使用群の方が低い 値を示し，う触抑制率は男子 $35.85 \%$ ，女子 $55.93 \%$ ，統計的にも有意のう触抑制効果が得られた。

健全歯ならびに期間中新萌出歯からの新う蜆発生はアパタイト歯磨剂使用群で明かに少なく，統計的にも 有意の差でう強予防勃果が珰められた。

以上のことから，合成ハイドロキシアパタイト配合歯磨郕の集団応用は，児童の新う䖵発生に有意の抑制 効果があることが示された。
\end{abstract}

\section{Koy words: Dentifrice, Hydroxyapatite, Caries prevention}

索引用語：㮀磨戍，ハイドロキシアパタイト，う蝕予防

\section{Introduction}

Tooth brushing is widely practiced in Japan. There are many primary schools where tooth brushing after school lunch is promoted in the school dental health program for prevention dental caries. Fluoride, dextranase, chlorhexidine, urease, and other agents are added to tooth pastes as supplmentary components, and these agents play a role in the prevention of dental caries and periodontal disease.

Hydroxyapatite is an inorganic constituent of mineralized biological tissues. Apatite is now used as a component of artificial bone in the medical field. This material is especially useful in dentistry, where it has been used in artificial tooth roots to support an implant denture, as a dental alveolar bone substitute,

* Department of Preventive Dentistry, Asahi University School of Dentistry (Director: Prof. Mizuo $K A N I)$

* 朝日大学歯学部口腔衛生学講座（主任：可児瑞夫教授） 
and in dental cement. Further development and clinical trials of these materials are currently being conducted as a substitute for tooth and bone.

The inorganic substance of teeth is hydroxyapatite. Initial caries progresses by decalcification of enamel. If this decalcified initial caries lesion could be repaired with apatite, then it would help to restore the tooth with the same inorganic component as the original tooth. It is possible for hydroxyapatite to remineralize a microdefect created in an apatite pellet or an artificial caries lesion ${ }^{1,2)}$. Since hydroxyapatite absorbs glucan produced by Streptococcus mutans ${ }^{3,4)}$ and salivary protein ${ }^{5.8)}$, a combination of apatite and salivary protein will inhibit plaque formation, and can be expected to enhance the effect of tooth brushing ${ }^{5}$.

From these facts, apatite containing dentifrices can be expected to have a cariostatic effect ${ }^{6,9}$. This study was designed for the purpose of evaluating the effect of clinical trial of an apatite containing dentifrice in caries prevention. A tooth brushing program was instituted and carried out for three years in primary schools. The study investigated the caries prevalence in school children who used dentifrice containing synthetic hydroxyapatite.

\section{Subjects of study and methods}

The tooth brushing program was conducted in three primary schools in Gifu Prefecture, Japan. Approximately 800 children participated in this program. The subjects of this study were 181 children (92 boys and 89 girls aged 9) (Table 1). These children were 4 th graders in 1983 , and the cohort study was

Table 1 Subjects of study

\begin{tabular}{lcc}
\hline \multirow{2}{*}{ Subjects } & \multicolumn{2}{c}{ No. of children } \\
\cline { 2 - 3 } & HA & Cont. \\
\hline Boys & 45 & 47 \\
Girls & 44 & 45 \\
\hline
\end{tabular}

HA : Study group used dentifrice contained $5 \%$ synthetic hydroxyapatite continued until they graduated from the school in the 6 th grade in 1986.

Dentifrices and tooth brushes were provided to the schools. The children in school $A$ used a $5 \%$ apatite containing dentifrice (Apato $\otimes)^{*}$, as a study group (apatite group). The children in schools $B$ and $C$ were given the same dentifrices without apatite (Kirara) as control. These children were only requested to use their own individual tooth brushing

techniques after every school lunch. This means that no specific dental health instructions were given, such as how to brush the teeth or about eating between meals. To encourage the children to brush after every lunch, the homeroom teacher of each class was asked to supervise the children an participate in this program.

Children who transferred to or from these schools during the study period or who were absent on the days of the dental examinations were conducted were excluded.

In April or May of each year, and at March graduation, each child received a precise oral examination for dental caries using a mirror and explorer, following the criteria recommended by the Japanese Society for Dental Health. Analysis was performed on the following items.

1. DMFT index on total erupted teeth

2. New caries incidence rate (New-DMFT rate) during the study period

(1) Based on sound teeth at the beginning of the study

(2) Based on newly erupted teeth during the study period

The examination data was recorded on mark sheet for automatic analysis. Card selector (S-680, TANAC) and multiple cross counter (PC-2000, TANAC) were used.

A statistically significant difference was examined by $\chi^{2}$-test.

* NIPPON ZEORA Co. Ltd. 


\section{Results}

1. DMFT index of total erupted teeth

At the beginning of the study, the total numbers of erupted teeth of the 4 th grade boys in the apatite and control groups was 12.69 and 12.66, showing no remarkable difference, whereas those of the 6 th grade boys differed by about 1.0 , namely, 22.51 vs. 23.82 . The same trend was seen in the total erupted teeth of girls, where in the 6 th graders, the values were $24.38 \mathrm{vs}, 25.31$; that is, the number of erupted teeth was larger in the control group (Table 2, Fig. 1).

The baseline data of DMFT indices in boys was 2.31 in the apatite group and 1.57 in the control group. At the termination of the study, three years later, DMFT indices in the groups were approximately the same (Table 2, Fig. 1). Annual increment of DMFT indices in bays showed no conspicuous difference after the initial and second years, but, after three years, a difference was found between the apatite and the control groups, 0.29 vs. 0.96 , respectively. Although, the baseline data of DMFT indices

Table 2 Number of mean erupted teeth and mean DMFT index in each subjects

\begin{tabular}{|c|c|c|c|c|c|c|}
\hline \multirow{2}{*}{\multicolumn{2}{|c|}{ Study group }} & \multicolumn{4}{|c|}{ School grade } & \multirow{2}{*}{$\begin{array}{l}\text { caries inhibition } \\
\text { rate }(\%)\end{array}$} \\
\hline & & 4 & 5 & 6 & $6^{*}$ & \\
\hline \multirow{2}{*}{ Boys } & $\mathrm{HA}$ & $2.31(12.69)$ & $2.76(16.40)$ & $3.29(19.84)$ & $3.58(22.51)$ & 35.86 \\
\hline & Cont. & $1.57(12.66)$ & $2.11(16.25)$ & $2.59(20.70)$ & $3.55(23.82)$ & - \\
\hline \multirow{2}{*}{ Girls } & $\mathrm{HA}$ & $2.68(15.70)$ & $2.91(19.47)$ & $3.68(21.98)$ & $4.13(24.38)$ & 55.93 \\
\hline & Cont. & $2.49(15.38)$ & $3.33(20.11)$ & $4.29(22.91)$ & $5.78(25.31)$ & - \\
\hline
\end{tabular}

( ) : mean number of erupted teeth

$6^{*}:$ March (graduation)

for girls was very similar in the two groups, a difference of DMFT indices was found at the yearly exams (Table 2, Fig. 1). Annual increment of DMFT indices was clearly lower in the apatite group than the control. DMFT increment in the apatite group of girls for three years was less than one half of the control.

The caries inhibition rates were $35.86 \%$ in boys and $55.93 \%$ in girls respectively, indicating a statistically significant difference between the apatite group and the control group.

2. New caries incidence rate during the study period

Two items were analysed concerning new caries incidence.

(1) Based on sound teeth at the beginning of the study

The new caries incidence in sound teeth at the beginning of the study showed no difference in boys of the two groups, with both groups showing the same degree of caries incidence. However the girls' new DMFT rate from

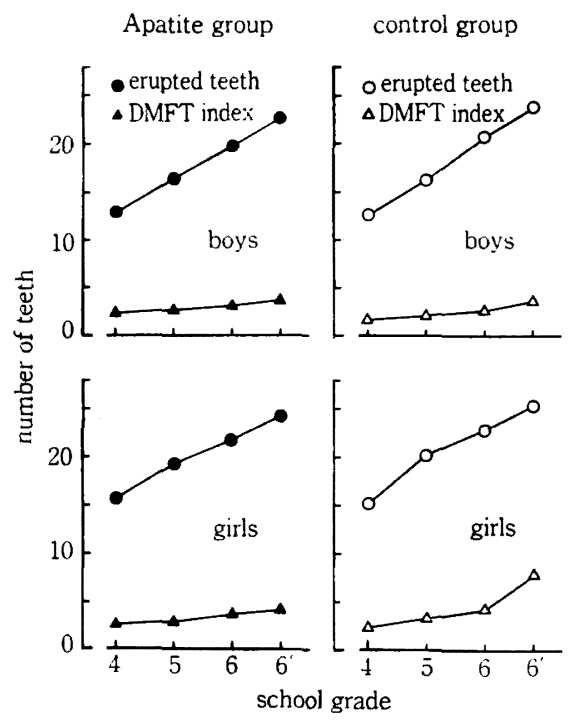

Fig. 1 Number of mean erupted teeth and mean DMFT index in each subjects 
Table 3 New caries incidence rate (new-DMFT rate)

(1) Based on sound teeth at the begining of the study

\begin{tabular}{|c|c|c|c|c|c|c|c|}
\hline \multirow{2}{*}{$\begin{array}{l}\text { Study } \\
\text { year }\end{array}$} & & \multicolumn{3}{|c|}{ Boys } & \multicolumn{3}{|c|}{ Girls } \\
\hline & & $\begin{array}{l}\text { No. of } \\
\text { teeth }\end{array}$ & $\begin{array}{l}\text { New } \\
\text { DMFT }\end{array}$ & $\begin{array}{l}\text { New DMFT } \\
\text { rate }(\%)\end{array}$ & $\begin{array}{l}\text { No. ot } \\
\text { teeth }\end{array}$ & $\begin{array}{l}\text { New } \\
\text { DMFT }\end{array}$ & $\begin{array}{l}\text { New DMFT } \\
\text { rate }(\%) \\
\end{array}$ \\
\hline \multirow[t]{2}{*}{1} & $\mathrm{HA}$ & 467 & 18 & 3.85 & 612 & 8 & $1.31^{* * * *}$ \\
\hline & Cont. & 488 & 20 & 4.10 & 580 & 29 & 5.00 \\
\hline \multirow[t]{2}{*}{2} & $\mathrm{HA}$ & 467 & 37 & 7.92 & 612 & 18 & 2.94 \\
\hline & Cont. & 488 & 34 & 6.97 & 580 & 51 & 8.79 \\
\hline \multirow[t]{2}{*}{3} & $\mathrm{HA}$ & 467 & 47 & 10.06 & 612 & 43 & $7.03^{* * * *}$ \\
\hline & Cont. & 488 & 49 & 10.04 & 580 & 83 & 14.31 \\
\hline
\end{tabular}

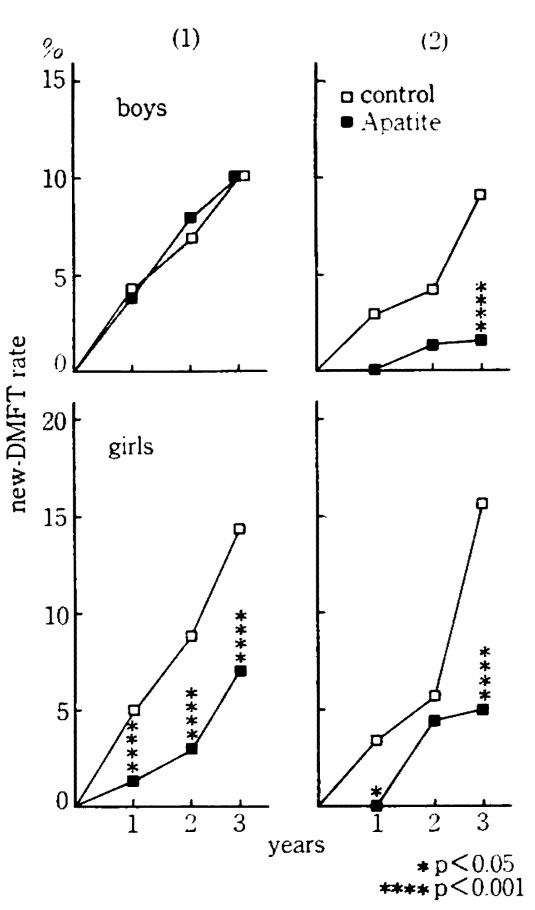

Fig. 2 New caries incidence rate (new. DMFT rate)

(1) Based on sound teeth at the beginning of the study

(2) Based on new erupted teeth during the study period sound teeth at the beginning of the study was very low in the apatite group compared with the control group after only one year. This was a statistically significant difference $(\mathrm{p}<0.001$ ) (Table 3, Fig. 2).

(2) Based on newly erupted teeth during the study period

There was no difference in the number of newly erupted teeth between the apatite and control groups during the study period for either boys or girls.

In the initial year, no caries incidence was found in the boys' apatite group, and a meager amount of caries was found in the control group. After three years, the rate was $1.56 \%$ in the apatite group and $9.16 \%$ in the control group. The inhibition of caries incidence in the apatite group was found to be statistically significant $(p<0.001$ ) (Table 4, Fig. 2 ). The girls' apatite group had no caries in the initial year. The values after three years were $5.00 \%$ in the apatite group and $15.60 \%$ in the control group, indicating a statistically significant difference $(p<0.001)$ (Table 4, Fig. 2).

The cariostatic effect of tooth brushing with apatite containing dentifrice was obtained in this group.

\section{Discussion}

This study was performed to evaluate the three year effect of clinical testing of the dentifrice contained $5 \%$ synthetic apatite on caries incidence in the primary school

children. Tooth brushing was performed in the school-based dental health program. The dentifrice used is commercialy available.

In the apatite group, the caries incidence of sound teeth at the beginning of the study and newly erupted teeth during the study period was clearly inhibited and the cariostatic effect was found (Table 3,4$)$. Shimura et al. ${ }^{9)}$ had school children of the 4 th, 5 th and 6 th grades perform tooth brushing after school 
Table 4 New caries incidence rate (new-DMFT rate)

(2) Based on new erupted teeth during the study period

\begin{tabular}{|c|c|c|c|c|c|c|c|}
\hline \multirow{2}{*}{$\begin{array}{l}\text { Study } \\
\text { year }\end{array}$} & & \multicolumn{3}{|c|}{ Boys } & \multicolumn{3}{|c|}{ Girls } \\
\hline & & $\begin{array}{l}\text { No. of } \\
\text { teeth }\end{array}$ & $\begin{array}{l}\text { New } \\
\text { DMFT }\end{array}$ & $\begin{array}{l}\text { New DMFT } \\
\text { rate }(\%)\end{array}$ & $\begin{array}{l}\text { No. of } \\
\text { teeth }\end{array}$ & $\begin{array}{l}\text { New } \\
\text { DMFT }\end{array}$ & $\begin{array}{l}\text { New DMFT } \\
\text { rate }(\%)\end{array}$ \\
\hline \multirow[t]{2}{*}{1} & $\mathrm{HA}$ & 147 & 0 & 0.00 & 166 & 0 & $0.00^{*}$ \\
\hline & Cont. & 134 & 4 & 2.99 & 175 & 6 & 3.43 \\
\hline \multirow[t]{2}{*}{2} & $\mathrm{HA}$ & 278 & 4 & 1.44 & 248 & 11 & 4.44 \\
\hline & Cont. & 309 & 13 & 4.21 & 350 & 20 & 5.71 \\
\hline \multirow[t]{2}{*}{3} & $\mathrm{HA}$ & 385 & 6 & 1.56 & 340 & 17 & $5.00^{* * * *}$ \\
\hline & Cont. & 404 & 37 & 9.16 & 391 & 61 & 15.60 \\
\hline
\end{tabular}

lunch, using dentifrice containing $5 \%$ hydroxyapatite similar to the dentifrice used in this study in order to examine the caries incidence in pit and fissures after one year in the study. They revealed that the caries inhibition rate on the DMFS was $26.42 \%$ after one year, indicating a statistically significant difference.

The cariostatic mechanism of apatite containing dentifrice may consists of the following :

(1) remineralization of caries lesions by hydroxyapatite ${ }^{1,2)}$, (2) adsorption of polysaccharide produced by Streptococcus mutans $s^{5,4}$, (3) protein adsorption ${ }^{5-8}$, and (4) tooth surface abrasive property ${ }^{5}$.

The adsorption of polysaccharides produced by Streptococcus mutans to hydroxyapatite was reported by Pearce et al. ${ }^{3}$. Shimura et al.4) also confirmed the adsorption ability of glucan produced by $S$. mutans to hydroxyapatite. Kuboki et al. ${ }^{8)}$ have shown that hydroxyapatite adsorbs salivary protein. Many studies have already reported these facts ${ }^{5-8)}$. The abrasiveness of the apatite containing dentifrice used in this study was similar to that of commercially available dentifrices, and there is no risk of abrading the tooth surfaces ${ }^{5)}$.

These properties of apatite seem to promote caries inhibition by use of an apatite containing dentifrice.

Caries extent and DMFS observation were not examined in this study. Shimura et al's one year clinical study also does not observe this point ${ }^{9}$. This will be studied in the future. However, Kuboki et al. "), show with an in vitro study that the adsorption ability of an apaptite pellet with a micro defect is greater with apatite than with dicalcium phosphate dihydrate. This suggests that there is a possibility of apatite pellet remineralization by apatite. The authors previously reported that dentifrices containing apatite facilitated remineralization of artificially formed caries lesions ${ }^{2}$. On the basis of this facilitation, apatite containing dentifrice can be expected to inhibit caries progression.

\section{Conclusion}

Fourth grade primary school children were directed to brush their teeth after school lunch using a dentifrice containing $5 \%$ synthetic hydroxyapatite. The study was carried out for 3 years in order to examine the cariostatic effect of apatite containing dentifrice. The following results were obtained.

1. The mean DMFT indices of total erupted teeth were low in apatite containing dentifrice group of boys and girls were significantly lower than those in non apatite dentifrice group. The caries inhibition rate in boys and girls were $35.86 \%$ and in $55.93 \%$, respectively.

2. The caries incidence rate of the sound teeth at the beginning showed significant difference after 
one year between two groups in girls but not boys.

3. The caries incidence based on newly erupted teeth was also lower in the apatite gruop.

4. The cariostatic benefit by the use of apatite containing dentifrice was discussed.

\section{Reference}

1) Kuboki, Y., Tazaki, M., Mizuno, M. and Fujita, K.: Demineralization, remineralization and microfilling restration of enamel surface. Dent. J., $26 ; 215,1987$.

2) Kani, T., Kani, M., Isozaki, A., Kato, H., Fukuoka, Y., Ohashi, T. and Tokumoto, T.: The effect of apatite-containing dentifrices on artificial caries lesions. J. Dent. Hlth., 38 ; 364, 1988.

3) Pearce, E. I. F. : Adsorption of streptococcal extracellular polysaccharides by hydroxyapatite. Archs Oral Biol., 21 ; 545, 1976.

4) Shimura, N. and Onisi, M.: The effect of $\mathrm{NaF}$ on the bacterial production of polysaccharide and subsequent adsorption on hydroxyapatite. J. Dent. Res., 57 ; 928, 1978.
5) Aoki, H., Shimura, N. and Kuboki, Y. : Plaque and hydroxyapatite. Dent. J., 15 ; 463, 1982.

6) Noshi, H.: Studies on the adosorption of proteins to synthetic hydroxyapatite. J. Osaka Odont. Soc., 49 ; 531, 1986.

7) Aoki, H., Akao, M., Shinozuka, O., Takagi, T., Tsuzaki, M. and Kuboki, Y.: Reaction of hydroxyapatite with human saliva. - Part I. Changes in crystallite sizes of hydroxyapatite reacted with salivary protein-- J. Dent. Mater., 1 ; 82, 1982.

8) Kuboki, Y., Shinozuka, O., Yamada, Y., and Miyake, M.: The clinical biochemical test for salivary proteins. Dent. J., 19 ; 247, 1984.

9) Shimura, N., Yonemitu, M., Nakamura, T., Hirayama, Y. and Takei, K. : Caries prevention and clinical trial of hydroxyapatite containing dentifrices(I). Dent. J., 15; 213, 1982. 